DOI: 10.34015/2523-4552.2021.1.08

УдК 343.3

Нетяга В. В., аспірант кафедри кримінального права та кримінології ННІ права Університету державної фіскальної служби України ORCID: 0000-0001-8250-7363

\title{
ПРОБЛЕМА ВИЗНАЧЕННЯ ОБ'ЄКТУ КОНТРАБАНДИ У ЧИННОМУ ЗАКОНІ ПРО КРИМІНАЛЬНУ ВІДПОВІДАЛЬНІСТЬ
}

У статті досліджено питання визначення об'єкту контрабанди у Кримінальному кодексі України. Проаналізовано наукові дослідження стосовно об'єкту кримінального правопорушення в цілому та контрабанди зокрема. Визначено, що переміщення через митний кордон України поза митним контролем або з приховуванням від митного контролю вибухових речовин, радіоактивних матеріалів, зброї або боєприпасів (крім гладкоствольної мисливської зброї або бойових припасів до неї), частин вогнепальної нарізної зброї, а також спеціальних технічних засобів негласного отримання інформації не входить до кримінальна-правової охорони суспільних відносин у сфері господарської діяльності. Запропоновано внести низку змін до чинного законодавства для поліпшення кримінально-правового урегулювання питання контрабанди.

Ключові слова: контрабанда; об'єкт; кримінальне правопорушення; зброя; технічні засоби.

В статье исследованы вопросы определения объекта контрабанды в Уголовном кодексе Украины. Проанализированы научные исследования по объекту уголовного преступления в целом и контрабанды в частности. Определено, что перемещение через таможенную границу Украины вне таможенного контроля или с сокрытием от таможенного контроля взрывчатых веществ, радиоактивных материалов, оружия или боеприпасов (кроме гладкоствольного охотничьего оружия или боеприпасов к нему), частей огнестрельного нарезного оружия, а также специальных технических средств негласного получения информации не входит в уголовно-правовой охраны общественных отношений в сфере хозяйственной деятельности. Предложено внести ряд изменений в действующее законодательство для улучшения уголовноправового урегулирования вопроса контрабанды.

Ключевые слова: контрабанда; объект; преступление; оружие; технические средства.

Постановка проблеми. Серед низки напрямів сучасної криміналь- ної політики України та інших країн особливого значення набуває про- 
тидія незаконному переміщенню через митний кордон товарів. Контрабанда завжди сприймалась суспільством як явище протиправне й суспільно небезпечне, що несе загрозу для економічних інтересів країни, громадської безпеки, норм моралі, безпеки життя, здоров'я населення та національної безпеки держави загалом. 3 огляду на це діяльність органів державної влади має бути націлена на правильність нормативно-правового регулювання цього явища, розробку механізмів запобігання та протидії контрабанді, зокрема шляхом посилення відповідальності, створення належних правових механізмів сприяння легальному переміщенню через державний кордон товарів, валюти, цінностей, іншого майна.

Аналіз останніх досліджень і публікацій. Теоретичною базою дослідження вивчення об'єкта в цілому та контрабанди зокрема виступають наукові праці вітчизняних та зарубіжних учених, які представляють різні галузі наукового знання, як-от: $\begin{array}{ll}\text { П. П. Андрушка, } & \text { О. Ф. Бантишева, }\end{array}$ Л.В.Багрій-Шахматова, І. М. Базярук, А. І. Бойко, $\quad €$. П. Гайворонського, В. О. Глушкова, О. О. Дудорова, М. П. Карпушина, М. Й. Коржанського, О. О. Кравченко, П. С. Матишевського, Н. А. Мирошниченка, М. І. Мельника, Ю. Б. Мельникова, А. А. Музики, В. О. Навроцького, Г. В. Паламарчук, О. В. Процюка, О. М. Омельчука, Л. Ю. Родіної, В. В. Сіленко, С. О. Сороки, О. Г. Степанової, М. С. Таганцева, Г. Б. Устинова, М. І. Хавронюка, П. С. Яні та інших. Водночас окремі важливі питання загального та родового об'єкту контрабанди зарубіжного залишились поза увагою науковців і потребують додаткових досліджень.
Постановка завдання. Метою статті $\epsilon$ визначення актуальних питань визначення об'єкту контрабанди у законі про кримінальну відповідальність для удосконалення кримінально-правових відносин у сфері господарської діяльності; громадської безпеки; авторитету органів державної влади, органів місцевого самоврядування, об'єднань громадян та кримінальні правопорушення проти журналістів.

Виклад основного матеріалу. Правильне вирішення питання про об'єкт кримінального правопорушення має важливе теоретичне i практичне значення. Саме об'єкт дозволяє визначити соціальну сутність кримінального правопорушення, з'ясувати його суспільно небезпечні наслідки, сприяє правильній кваліфікації діяння, а також відокремленню його від суміжних суспільно небезпечних посягань. Слід зазначити, що основним об'єктом кримінального правопорушення $є$ ті суспільні відносини, зміна яких складає соціальну суть кримінального правопорушення, 3 метою охорони яких прийнята кримінально-правова норма, що передбачає відповідальність за його вчинення [1, с. 30-31].

Саме тому законодавець питання про кримінальну відповідальність за контрабанду відніс до розділу VII «Кримінальні правопорушення у сфері господарської діяльності» Особливої частини КК України. Водночас варто зауважити, що $з$ моменту прийняття цього закону до внесення відповідних змін у 2011 році ст. 201 КК Україна визначала відповідальність за товарну контрабанду у великих розмірах, тому як мінімум за цією ознакою віднесення цього кримінального 
правопорушення до вчинених у сфері господарської діяльності виглядає цілком аргументованим. Однак нині, як нам вважається, виникла необхідність перегляду певних теоретичних засад щодо контрабанди як суто господарського кримінального правопорушення.

Отже, на сучасному етапі дослідження нами пропонується розглянути необхідність віднесення контрабанди до кримінальних правопорушень у сфері господарської діяльності відповідно до його об'єкту та предмету, а також доцільність їх гуртування в одній кримінальноправовій нормі, зокрема як розмежування за різними статтями та частинами. Крім того, вважаємо за доцільне розглянути можливість утворення нової кримінальноправової норми із винесенням до іншого розділу певних предметів контрабанди, що за своїми якостями, як вважається, недоцільно розміщені в статті, що регламентує відповідальність за господарське кримінальне правопорушення.

На нашу думку, для дослідження можливості таких досить кардинальних змін варто насамперед визначитися щодо об'єкту згаданого кримінального правопорушення. Саме це питання впродовж всього існування цієї кримінально-правової норми викликало найбільші суперечки. Не випадково визначення об'єкту кримінального правопорушення дає можливість визначити те коло суспільних відносин, якому першочергово спричиняється шкода у разі суспільно-небезпечному посяганні.

Насамперед варто відзначити, що юридичне значення об'єкта кримінального правопорушення полягає у його обов'язковості як елемента будь-якого складу кримінального правопорушення [2, с. 5; 3, с. 34]. Через це, можемо прийти до висновку, що вирішення питань кваліфікації кримінального правопорушення неможливе без дослідження його об'єкту. Такий аналіз, на нашу думку, необхідно проводити в паралельному дослідженні предмету контрабанди, що підтверджується й думкою багатьох авторів, які переконані, що предмет кримінального правопорушення допомагає при встановленні об'єкту злочинного посягання [4, c. $56 ; 5$, с. 35$]$.

3і свого боку, конкретизація об’єкта кримінального правопорушення дозволяє виявити ступінь та соціальні властивості заподіяної злочином суспільно небезпечної шкоди, підстави та критерії вибору об'єктів кримінально-правової охорони і засобів захисту, а також побудови кримінального закону i кваліфікації кримінального правопорушення [6, с. 11]. Важливо відзначити, що в науці кримінального права панує точка зору, відповідно до якої об'єктом будь-якого кримінального правопорушення $\epsilon$ відповідні суспільні відносини [7, с. $51 ; 8$, с. 41 ; 9, с. 36].

Водночас варто зазначити, що серед вітчизняних та зарубіжних науковців відзначалось, що невиправдано визначати суспільні відносини як об’єкт в кримінальних правопорушеннях проти особи, а тому, на їхню думку, більш доречним для встановлення суті явищ використовувати теорію об'єкта як певного блага або цінності [10, с. 123; 11, с. 84]. Так, А. В. Наумов, не заперечуючи, що в багатьох кримінальних правопорушеннях суспільні відносини - це об'єкт, стверджує, що на деякі кри- 
мінальні правопорушення таке розуміння об'єкта не поширюється, і тому, на його думку, для встановлення об'єктів низки кримінальних правопорушень слід «повернення до теоpiї об’єкта як правового блага, створеної ще наприкінці минулого століття в межах класичної та соціологічної шкіл кримінального права» $[12$, с. 147]. Представник російської школи вчених-юристів А. В. Пашковська взагалі пропонує в усіх випадках вважати об'єктом злочину «охоронювані кримінальним законом соціально значущі цінності, інтереси, блага, на які посягає особа, яка вчинила злочин, i яким заподіюється або може бути заподіяна шкода» $[13$, с. 202].

Ми абсолютно підтримує окреслену позицію більшості вчених тим паче, що такий висновок грунтується також і на чинному законодавстві. Наприклад, у ч. 1 ст. 1 КК України прямо вказано, що кримінальний закон України має на меті правове забезпечення охорони прав і свобод людини і громадянина, власності, громадського порядку і громадської безпеки, довкілля, конституційного устрою України від злочинних посягань, забезпечення миру і безпеки людства, також запобіганню злочинам [4]. Отож, позиція, що об'єкт кримінального правопорушення - це охоронювані кримінальним законом суспільні відносини, найбільш розроблена та актуальна на сьогоднішній час, тому ми об'єкт контрабанди будемо розглядати згідно з цією позицією.

Природно, що об'єктом кримінальних правопорушень $\epsilon$ не будьякі суспільні відносини, а лише ті, що поставлені під охорону закону про кримінальну відповідальність.
Визначитись із цим питанням допоможе лише вірна кваліфікація об'єктів кримінальних правопорушень, що має важливе практичне та теоретичне значення для з'ясування виду суспільних відносин, що знаходяться під охороною кримінального права та практику застосування діючих кримінально-правових норм. Не поглиблюючись у наукову дискусію вчених стосовно правильності тієї чи іншої системи класифікації об'єкту кримінального правопорушення, за основу у нашому дослідженні ми візьмемо встановлені наукою та практикою кримінального права положення, згідно яких усі об'єкти потрібно кваліфікувати в залежності:

- від ступеню узагальненості охоронюваних кримінальним правом суспільних відносин, виступаючих об'єктами різних кримінальних правопорушень (класифікація по «вертикалі»);

- від важливості охоронюваних суспільних відносин, яким причиняє шкоду конкретний злочин (класифікація безпосередніх об'єктів по «горизонталі») [4, с. 41].

Отже, об'єктом будь-якого кримінального правопорушення завжди виступають об'єктивно існуючі в суспільстві відносини, що поставлені під охорону кримінального закону. Самі ці відносини дуже різноманітні (економічні, соціальнополітичні, ідеологічні та ін.) і регулюються в суспільстві різними соціальними нормами (нормами права, моралі, моральності, звичаями).

Загальний об'єкт утворює сукупність (економічні, політичні, основи національної безпеки, власності, життя і здоров'я людей тощо) суспільних відносин, що поставлені 
під охорону чинного кримінального законодавства. Зі свого боку, загальним об'єктом кримінального правопорушення $\epsilon$ не постійна система суспільних відносин (раз і назавжди дана), а рухлива (мінлива) система, що залежить від кримінального закону (наприклад, у зв'язку з криміналізацією чи декриміналізацією суспільно небезпечних діянь змінюється і вся система суспільних відносин, що утворює загальний об'єкт кримінально-правової охорони) $[15$, с. 41$]$.

Значення родового об'єкта кримінального правопорушення полягає насамперед у тому, що він дозволяє провести класифікацію всіх кримінальних правопорушень і кримінально-правових норм, що встановлюють відповідальність за їхнє вчинення. Саме ця властивість була покладена в основу при побудові Особливої частини кримінальних кодексів, що дозволило законодавцю в цілому правильно об'єднати в межах однієї глави КК норми, у яких передбачається відповідальність за зазіхання на тотожні чи однорідні суспільні відносини [16, с. 85].

Так, у розділі VII Особливої частини КК України «Кримінальні правопорушення в сфері господарської діяльності» включені норми про відповідальність за зазіхання на існуючу в нашій державі систему господарювання, що виглядає цілком слушно, враховуючи, що на момент прийняття КК, контрабанда включала незаконне переміщення через митний кордон товарів у великих розмірів, однак наразі положення у цьому розділі цієї норми видається дискусійним.

Очевидно, що при протиправному переміщенні через митний кордон України товарів та предметів контрабандним шляхом порушується порядок державного регулювання зовнішньоекономічної діяльності через порушення встановленого порядку переміщення товарів та предметів через кордон, що, зі свого боку, призводить до заподіяння прямих економічних збитків державі, пов'язаних з несплатою мита, інших податків (платежів) як під час перетинання митного кордону України, так і після ввезення товарів на територію України. Також значних збитків економіці завдає реалізація контрабандних товарів на території України або за її межами. Крім того, контрабанда посягає на національну культурну спадщину українського народу, може заподіяти шкоди відносинам 3 іншими державами у сфері економічних відносин. Виходячи із вищезазначеного та погоджуючись із більшістю авторів, варто визначити, що у такій редакції родовим об'єктом складу кримінального правопорушення «Контрабанда» (ст. 201 КК України) охоронювані кримінальним законом суспільні відносини щодо забезпечення господарської діяльності в Україні [17, с. 11].

Водночас варто відзначити, що ст. 201 КК України передбачає відповідальність за переміщення через митний кордон України поза митним контролем або з приховуванням від митного контролю вибухових речовин, радіоактивних матеріалів, зброї або боєприпасів (крім гладкоствольної мисливської зброї або бойових припасів до неї), частин вогнепальної нарізної зброї. Однак, як відомо, кримінальні правопорушення, пов'язані із незаконним обігом зброю та боєприпасів, знаходяться у розділі IX «Кримінальні правопорушення 
проти громадської безпеки». Тобто, родовим об'єктом цих кримінальних правопорушень $\epsilon$ громадська безпека, що забезпечує стан захищеності життєдіяльності людей від джерел підвищених небезпек, зокрема зброї та інших смертоносних предметів. До цієї групи належать кримінальні правопорушення, як-от: незаконне поводження зі зброєю, бойовими припасами, вибуховими речовинами (ст. 263 КК України) чи радіоактивними матеріалами (ст. 265 КК України), недбале зберігання зброї (ст. 264 КК України), викрадення, привласнення, вимагання вогнепальної зброї, вибухових речовин чи радіоактивних матеріалів або заволодіння ними шляхом шахрайства або зловживання службовим становищем (ст. 262 КК України) [14].

Отже, обов'язковою ознакою об'єкту цих кримінальних правопорушень є смертоносні предмети, якот: зброя, боєприпаси, вибухові речовини та пристрої, радіоактивні матеріали та інші предмети, що становлять підвищену небезпеку для оточення. Вони виступають як предмети або знаряддя цих кримінальних правопорушень та обумовлюють загально небезпечний характер останніх [18, с. 187]. Безумовно, предмет як ознака об'єкта кримінального правопорушення впливає на його зміст і структуру, тому законодавець їх виділяє з урахуванням особливого правового режиму, зумовленого їх шкідливими властивостями на предмет посягання.

Через це ми впевнені, що контрабанда цих предметів насамперед посягає на суспільні відносини у сфері громадської безпеки, а не у сфері господарської діяльності як відніс їх законодавець. Отому ми пропонуємо виключити зі ст. 201 КК України положення про вибухові речовини, радіоактивні матеріали, зброю або боєприпаси, частини вогнепальної нарізної зброї та відповідно у розділі «Кримінальні правопорушення проти громадської безпеки» норму, що передбачає відповідальність за викрадення, привласнення, вимагання вогнепальної зброї (крім гладкоствольної мисливської), бойових припасів, вибухових речовин, вибухових пристроїв чи радіоактивних матеріалів або заволодіння ними шляхом шахрайства (ч. 1 ст. 262 КК України) доповнити положення про кримінальну заборону за переміщення через митний кордон України поза митним контролем або 3 приховуванням від митного контролю цих предметів.

Крім того, у ст. 201 КК України передбачається відповідальність за контрабанду спеціальних технічних засобів негласного отримання інформації, і знову ж таки постає питання щодо правильності визначення об'єкту цього кримінального правопорушення через його предмет. Ці засоби були включені до ст. 201 КК України завдяки змінам у законодавство у 2011 році. Однак, на наше переконання, через предмет злочинного посягання об'єктом цього правопорушення виступають не суспільні відносини у сфері господарської діяльності і доцільніше їх розмістити в іншому розділі КК України. Наприклад, вітчизняний вчений Н.А. Мирошниченко пропонує таку контрабанду віднести до розділу XVI КК України «Кримінальні правопорушення у сфері використання електронно-обчислювальних машин (комп'ютерів), систем та комп'ю- 
терних мереж і мереж електрозв'язку» [19, с. 212].

Однак, ми не можемо погодитись із зазначеними вченим, адже зміст технічних засобів негласного отримання інформації в одержанні незаконним шляхом таємної інформації, а тому, на наше переконання, їх не можна віднести до системи суспільних відносин, що регулюють сфері використання електроннообчислювальних машин (комп'ютерів), систем та комп'ютерних мереж і мереж електрозв'язку. Тим паче, у розділі XV «Кримінальні правопорушення проти авторитету органів державної влади, органів місцевого самоврядування, об'єднань громадян та кримінальні правопорушення проти журналістів» наявна норма, передбачає відповідальність за незаконні придбання, збут або використання спеціальних технічних засобів отримання інформації (ст. 359 КК України), яку, на нашу думку, варто доповнити новою частиною, що передбачала би відповідальність за контрабанду спеціальних технічних засобів негласного отримання інформацї̈.

В цілому такий розподіл об'єкту контрабанди за відповідними розділами КК України виглядає доцільним і цілком логічним, адже у вітчизняному законі про кримінальну відповідальність разом із загальною нормою про контрабанду (ст. 201 КК України) передбачена спеціальна норма (ст. 305 КК України), що встановлює відповідальність за контрабанду наркотич- них засобів, психотропних речовин, їх аналогів чи прекурсорів або фальсифікованих лікарських засобів. Спеціальна норма (ст. 305 КК України) розташована у розділі XIII Особливої частини КК України «Злочини у сфері обігу наркотичних засобів, психотропних речовин, їх аналогів або прекурсорів та інші злочини проти здоров'я населення» [14]. Так, родовим об'єктом цих кримінальних правопорушень можна визначити здоров'я населення, що включає безпеку неозначеного кола осіб від незаконного обігу наркотичних засобів, психотропних речовин, їх аналогів і прекурсорів.

Висновки. Насамкінець, варто визначити, що об'єкт контрабанди згідно з чинною редакцією ст. 201 КК України не в повній мірі відповідає характеру та суті кримінального правопорушення у сфері господарської діяльності. Отож, слід внести зміни до ст. 201, 262, 305 та 359 КК України, уточнивши як об'єкт, так і предмет контрабанди та узгодити зміст загальної та спеціальної норми. Окреслене дозволить змінити вектор кримінально-правової охорони норми. Крім того, ознаки предмета впливають на визначення об'єкта та на кваліфікацію злочинів. Вони також є підставою віднесення певних діянь до кримінально-правової або адміністративної юрисдикції (контрабанда товарів, зброї, наркотичних речовин, спеціальних технічних засобів негласного отримання інформації тощо).

\section{Список використаних джерел}

1. Коржанский Н. И. Объект посягательства и квалификация преступлений. Волгоград, 1976. 278 с.

2. Глистин В.К. Проблема уголовно-правовой охраны общественных отношений (объект и квалификация преступлений). Луганск : Изд-во ЛГУ, 1979. 127 с. 
3. Тацій В. Я. Об’єкт і предмет злочину в кримінальному праві : монографія. Харків, 2016. 256 с.

4. Таций В. Я. Объект преступления. Уголовное право Украины. Общая часть. Харьков: Вища школа, 1999. 78 с.

5. Корнеева А. В. Теоретические основы квалификации преступлений / под ред. А. И. Рарога. Москва, 2009. 176 с. $112 \mathrm{c}$.

6. Коржанський М. Й. Об’єкт і предмет злочину : лекція. Київ: НАВСУ, 1997.

7. Кримінальне право України. Загальна частина : навчальний посібник / В. М. Трубников та ін. ; за заг. ред. В. М. Трубникова. Харків : ХНУ ім. В. Н. Каразіна, 2015. $444 \mathrm{c}$.

8. Митрофанов А.А. Основні напрямки кримінально-правової політики в Україні: формування та реалізація : дис. ... канд. юрид. наук : 12.00.08. Одеса, 2005. 187 c.

9. Науково-практичний коментар Кримінального кодексу України / за ред. М. І. Мельника, М. І. Хавронюка. 11-е вид., переробл. та доповн. Київ: ВД «Дакор», 2019. 1387 c.

10.Кримінальне право України. Загальна частина : підручник для студ. юрид. вузів і фак. / Г. В. Андрусів, П. П. Андрушко, В.В. Беньківський та ін. ; за ред. П. С. Матишевського та ін. Київ: Юрінком-Інтер, 1997. 512 с.

11. Российское уголовное право. Общая часть : учебник / под ред. В. Н. Кудрявцева, А. В. Наумова. Москва: Юристъ, 1997. 657 с.

12. Наумов А. В. Российское уголовное право: курс лекций: в 3 т. Москва: Волтерс Клувер, 2011. Т. 1: Общая часть. 768 с.

13.Курс уголовного права. Общая часть: учебник для вузов / под ред. Н. Ф. Кузнецовой, И. М. Тяжковой. Москва: Зерцало, 1999. Том I: Учение о преступлении. 624 с.

14.Кримінальний кодекс України : Закон України від 5.04.2001 p. № 2341-III. URL: http://zakon.rada.gov.ua/laws/show/2341-14 (дата звернення: 17.03.2021).

15. Бандурка I. O. Об'єкт злочину як кримінально-правова категорія. Право.uа. 2015. № 2. С. 70-75.

16. Шевчук В. В., Охман О. В. Об’єкт злочину за кримінальним правом України. Університетські наукові записки. 2006. № 2. С. 234-239.

17. Омельчук О. М. Контрабанда за кримінальним правом України : автореф. дис. ... канд. юрид. наук : 12.00 .08 / Київський національний ун-т ім. Тараса Шевченка. Київ, 2002. 20 c.

18. Кириченко О. В. Громадська безпека як об’єкт кримінально-правової охорони. Право і суспільство. 2012. № 3. С. 185-190.

19. Мирошниченко Н. А. Об’єкт та предмет кримінально-караної контрабанди. Традиції та новації юридичної науки: минуле, сучасність, майбутнє : матер. Міжнар. наук.-практ. конф. (Одеса, 19 трав. 2017 р.). У 2-х т. / відп. ред. Г. О. Ульянова. Одеса : ВД «Гельветика», 2017. Т. 2. С. 211-213.

\section{References}

Korzhanskij, N. I. (1976). Obekt posyagatelstva i kvalifikaciya prestuplenij. Volgograd.

Glistin, V.K. (1979). Problema ugolovno-pravovoj ohrany obshestvennyh otnoshenij (obekt $\mathrm{i}$ kvalifikaciya prestuplenij). Lugansk : Izd-vo LGU. Harkiv.

Tacij, V. Ya. (2016). Ob'yekt i predmet zlochinu v kriminalnomu pravi : monografiya.

Tacij, V. Ya. (1999). Obekt prestupleniya. Ugolovnoe pravo Ukrainy. Obshaya chast. Harkov: Visha shkola. 
Korneeva, A. V. (2009). Teoreticheskie osnovy kvalifikacii prestuplenij. Moskva. Korzhanskij, M. J. (1997). Ob'yekt i predmet zlochinu. Kiyiv: NAVSU, 1997. 112 Trubnikov, V. M. (red.). (2015).Kriminalne pravo Ukrayini. Zagalna chastina. Harkiv: HNU im. V. N. Karazina.

Mitrofanov, A. A. (2005). Osnovni napryamki kriminalno-pravovoyi politiki v Ukrayini: formuvannya ta realizaciya (dis. ... kand. yurid. nauk). Odesa.

Naumov, A. V. (2011). Rossijskoe ugolovnoe pravo: kurs lekcij: v 3 t. Moskva: Volters Kluver.

Kuznecova, N. F. (1999). Kurs ugolovnogo prava. Obshaya chast. Moskva: Zercalo.

Bandurka, I. O. (2015). Ob'yekt zlochinu yak kriminalno-pravova kategoriya. Pravo.ua, 2, 70-75.

Shevchuk, V. V., Ohman, O. V. (2006). Ob'yekt zlochinu za kriminalnim pravom Ukrayini. Universitetski naukovi zapiski, 2, 234-239.

Omelchuk, O. M. (2002). Kontrabanda za kriminalnim pravom Ukrayini. (avtoref. dis. ... kand. yurid. Nauk). Kiyivskij nacionalnij un-t im. Tarasa Shevchenka. Kiyiv.

Kirichenko, O. V. (2012). Gromadska bezpeka yak ob'yekt kriminalno-pravovoyi ohoroni. Pravo i suspilstvo, 185-190.

Miroshnichenko, N. A. (2017). Ob'yekt ta predmet kriminalno-karanoyi kontrabandi. Tradiciyi ta novaciyi yuridichnoyi nauki: minule, suchasnist, majbutnye : mater. Mizhnar. nauk.-prakt. konf. (Odesa, 19 trav. 2017 r.), 2, 211-213. Ukraine

V. Netyaga, Postgraduate student of the University of the State Fiscal Service of

ORCID: 0000-0001-8250-7363

\section{The problem of determining the object of smuggling in the current law on criminal liability}

The article studies the issues of determining the object of smuggling in the Criminal Code of Ukraine. Scientific studies on the object of a criminal offense in general and smuggling in particular were analyzed. It is proposed to consider the need to assign smuggling to criminal offenses in the field of economic activity in accordance with its object and object, as well as the feasibility of their unification in one criminal law norm, in particular as a distinction between different articles and parts. In addition, we consider it advisable to consider the possibility of creating a new criminal law norm with the introduction of certain items of smuggling into another section, which, in terms of their qualities, is considered inappropriate to be placed in the article regulating liability for an economic criminal offense.

It is determined that movement across the customs border of Ukraine outside customs control or with concealment from customs control of explosives, radioactive materials, weapons or ammunition (except for smooth-bore hunting weapons or ammunition), parts of rifled firearms, as well as special technical means of secretly obtaining information is not included in the criminal legal protection of public relations in the field of economic activity. In addition, the characteristics of the object affect the definition of the object and the qualification of crimes. They are also grounds for attributing certain acts of criminal or administrative jurisdiction 
(smuggling of goods, weapons, narcotic substances, special technical means of secretly obtaining information).

It is justified that a common object forms a combination (economic, political, basis of national security, property, life and health of people, etc.) of public relations placed under the protection of the current criminal law. For its part, the general object of a criminal offense is not a permanent system of public relations (once and for all given), but a mobile (variable) system, depends on the criminal law (for example, in connection with the criminalization or decriminalization of socially dangerous acts, the entire system of public relations changes, forms a common object of criminal legal protection).

It is determined that the object of smuggling in accordance with the current version of Art. 201 of the Criminal Code of Ukraine does not fully correspond to the nature and essence of the criminal offense in the field of economic activity. Thus, amendments should be made to Art. 201, 262, 305 and 359 of the Criminal Code of Ukraine, specifying both the object and the subject of smuggling and agreeing on the content of the general and special norm. The outline will change the vector of criminal law protection of the norm. It is proposed to introduce a number of amendments to the current legislation to improve the criminal legal settlement of the issue of smuggling.

Keywords: smuggling; object; criminal offense; weapons; technical means; economic activity. 